\title{
PENGARUH RENDAM AIR GARAM TERHADAP PROSES PENYEMBUHAN UKUS DIABETIKUM
}

\author{
Moh Projo Angkasa ${ }^{1}$, Ta'adi $^{2}$, Mardi hartono ${ }^{3}$ \\ Prodi D III Keperawatan Pekalongan, Jurusan Keperawatan, \\ Poltekkes Kemenkes Semarang \\ E-mail: projoangkasa@gmail.com
}

\begin{abstract}
Abstrak
Prevalensi terjadinya ulkus diabetikum di Indonesia sebesar 15\% dan sering kali berakhir dengan kecacatan dan kematian (Waspadji, 2006). Penyembuhan luka sangat dipengaruhi oleh metode perawatan luka. Banyak tehnik perawatan luka.Salah satunya dengan menggunakan air garam.Garam merupakan benda padatan berwarna putih berbentuk kristal yang merupakan kumpulan senyawa dengan bagian terbesar Natrium klorida $(\mathrm{NaCl})$ lebih dari $80 \%$ serta senyawa lainnya seperti Magnesium klorida, Magnesium Sulfat, kalsium klorida dan lain-lain. Garam mempunyai sifat yang mudah menyerap air. Ketika garam dicampur dengan air, terutama air hangat, terbentuklah partikel-partikel dengan muatan listrik yang berbeda: ion natrium yang bermuatan positif dan ion klor yang bermuatan negatif. Ketika larutan garam ini diberikan pada bagian yang luka, ion-ion ini akan mengatur tekanan sel-sel di sekitar luka. Tekanan diatur sedemikian rupa sehingga cairan tidak akan keluar dari dalam sel. Dengan kata lain, luka akan menjadi cepat kering.Di samping mengeringkan luka, air garam juga dapat membunuh bakteri yang menyerang luka (terutama bakteri staphylococcus dan streptococcus. Tujuan penelitian untuk mengetahui pengaruh rendam air garam terhadap proses penyembuhan luka ulkus diabetikum. Desain penelitian ini menggunakan quasi eksperimen dengan rancangan randomized control group only design. Populasi pada penelitian ini adalah seluruh pasien dengan ulkus diabetikum di RS Prima Medika Pemalang. Sampel yang diambil dalam penelitian ini adalah dari populasi. Teknik pengambilan sampel yang dipakai dalam penelitian ini adalah quota sampling. Pada penelitian ini sampel berdasarkan kuota yang telah di tetapkan peneliti yaitu sejumlah 40 responden, 20 responden dilakukan tindakan rendam air garam, dan 20 responden tidak dilakukan rendam air garam sebagai kontrol. Analisa menggunakan univariat dan bivariate. Analisa bivariat dilakukan dengan menggunakan uji beda mean independent menggunnakan uji non parametric MannWhitney $U$ karena distribusi data tidak normal. Hasil penelitian menunjukkan bahwa rata-rata nilai proses penyembuhan luka pada kelompok intervensi (direndam air garam) adalah 3.70, sedangkan rata-rata nilai proses penyembuhan luka pada kelompok kontrol (tidak direndam air garam) adalah 3.35. Hasil uji statistik didapatkan ada pengaruh perawatan luka rendam air garam terhadap proses penyembuhan luka ulkus diabetikum $(\mathrm{p}$ value $=0.029)$
\end{abstract}

Kata kunci: Proses penyembuhan ulkus diabetikum, Rendam air garam 


\section{Pendahuluan}

Diabetes termasuk penyakit kronis yang terjadi ketika pankreas tidak menghasilkan cukup insulin atau ketika tubuh tidak dapat secara efektif menggunakan insulin yang dihasilkan.Insulin adalah hormon yang mengatur gula darah.Hiperglikemia merupakan efek umum dari diabetes yang tidak terkontrol dan dari waktu ke waktu menyebabkan kerusakan serius pada banyak sistem tubuh, khususnya saraf dan pembuluh darah (WH0, 2015).

Pasien dengan DM Tipe 2 dapat menjalani hospitalisasi dengan berbagai komplikasi, seperti ulkus kaki diabetik (diabetic foot ulcer), retinopati, AKI (Acute Kidney Injury), syok sepsis, CHF (Congestive Heart Failure), PAD (Peripheral Artrial Disease), dan lain-lain. Salah satu komplikasi diabetes mellitus yang ditakuti masyarakat adalah ulkus kaki diabetik (diabetic foot ulcer), yaitu infeksi, ulserasi, dan atau destruksi jaringan ikat dalam yang berhubungan dengan neuropati dan penyakit vaskuler perifer pada tungkai bawah. Penderita diabetes mellitus dengan ulkus kaki diabetik kurang mampu merasakan suhu panas atau dingin serta sensasi rasa sakit sehingga berisiko mengalami luka hingga dua kali lipat dibanding bukan penderita diabetes mellitus. Luka ulkus kaki diabetik bersifat kronik dan cenderung mengandung mikroorganisme patogen meskipun luka dalam kondisi tidak terinfeksi. Komplikasi ulkus kaki diabetik merupakan penyebab tersering dilakukannya amputasi dengan risiko 15-40 kali lebih besar dibanding dengan non-DM. Komplikasi ulkus menyebabkan lama rawat menjadi lebih panjang.Lebih dari $25 \%$ penderita DM yang dirawat adalah akibat ulkus kaki diabetik (Decroli et al, 2008).

Permasalahan Ulkus diabetikum di Indonesia merupakan permasalahan yang belum dapat terkelola dengan baik. Prevalensi terjadinya ulkus diabetikum di Indonesia sebesar 15\% dan sering kali berakhir dengan kecacatan dan kematian (Waspadji, 2006). Upaya untuk meminimalkan terjadinya kecacatan atau amputasi bahkan kematian akibat ulkus diabetikum adalah dengan melakukan perawatan luka agar luka segera sembuh dan tidak terjadi infeksi, dimana dalam hal ini peran perawat sangat penting karena perawat bertugas melakukan perawatan luka bersama dengan dokter dan petugas medis 
lain. Penyembuhan luka di pengaruhi oleh beberapa faktor, diantaranya yaitu nutrisi, kelembaban, usia, gangguan oksigenasi, gangguan suplai darah, eksudat yang berlebihan, jumlah jaringan nekrotik, perawatan luka, obat-obatan dan stress luka (Morison, 2004).

Garam mempunyai sifat yang mudah menyerap air. Ketika garam dicampur dengan air, terutama air hangat, terbentuklah partikel-partikel dengan muatan listrik yang berbeda: ion natrium yang bermuatan positif dan ion klor yang bermuatan negative, larutan garam ini diberikan pada bagian yang luka, ion-ion ini akan mengatur tekanan sel-sel di sekitar luka. Tekanan diatur sedemikian rupa sehingga cairan tidak akan keluar dari dalam sel .Di samping mengeringkan luka, air garam juga dapat membunuh bakteri yang menyerang luka (terutama bakteri staphylococcus dan streptococcus. Berdasarkan fenomena dan penjelasan diatas maka masalah dalam penelitian ini adalah "Adakah pengaruh rendam air garam terhadap proses penyembuhan ulkus diabetikum di Rumah Sakit Prima Medika Pemalang ?:

\section{Tinjauan Teori}

a. Luka

Luka yaitu kontinuitas kulit yang terputus termasuk jaringan yang ada di bawahnya (Setioputro et al, 2010). Luka adalah suatu kondisi kulit, mukosa membran, tulang atau organ tubuh lain yang mengalami kerusakan kontinuitas atau cedera (Kozier, 2009). Proses penyembuhan luka melibatkan integritas proses fisiologi. Sifat penyembuhan pada semua luka sama, dengan variasinya yang bergantung pada lokasi, tingkat keparahan, dan luas luka. Proses penyembuhan luka juga dipengaruhi oleh kemampuan sel dan jaringan dalam melakukan regenerasi ke strukur normal, misalnya sel hati, tubulus ginjal dan neuron pada sistem saraf pusat mengalami regenerasi sel yang lambat atau bahkan tidak beregenerasi sama sekali (Potter dan Perry, 2005b).

Morison (2004) membagi proses penyembuhan luka dalam empat fase, yaitu fase inflamasi, fase destruktif, fase poliferatif, dan fase maturasi. Menurut Gitarja (2014) ada tiga fase yaitu fase inflamasi, fase poliferasi dan fase maturasi. 
b. Ulkus diabetikum

Ulkus diabetikum adalah luka yang terjadi karena adanya kelainan pada saraf, pembuluh darah dan kemudian adanya infeksi. Apabila infeksi tidak diatasi dengan baik, hal itu akan berlanjut menjadi pembusukan bahkan dapat diamputasi (Situmorang, 2009). Gangren adalah luka diabetikum yang sudah membusuk dan bisa melebar, ditandai dengan jaringan yang mati berwarna kehitaman dan berbau karena disertai pembusukan oleh bakteri (Situmorang, 2009).

Terjadinya ulkus diabetikum tidak terlepas dari tingginya kadar glukosa darah pasien diabetes mellitus. Tingginya kadar gula darah yang berkelanjutan dan dalam jangka waktu lama dapat menyebabkan kelainan neuropati dan kelainan pada pembuluh darah kemudian menimbulkan masalah pada kaki pasien diabetes mellitus (Sudoyo et al, 2006). Ada tiga komplikasi diabetes mellitus yang dapat meningkatkan risiko terjadinya infeksi kaki pada pasien diabetes mellitus, yaitu neuropati, penyakit vaskuler perifer dan penurunan daya imunitas. Ketiga komplikasi tersebut juga bermula dari tingginya konsentrasi glukosa dalam darah (Morison, 2004)

Klasifikasi ulkus diabetikum menurut Wagner lebih mengacu pada pengelolaan atau manajemen luka diabetikum. Wagner mengklasifikasikan luka diabetikum berdasarkan luas dan kedalaman luka (Sudoyo at al, 2006), yaitu:

a. Derajat 0 , kulit utuh tetapi ada kelainan pada kaki akibat neuropati

b. Derajat I, yaitu terdapat ulkus superfisial, terbatas pada kulit

c. Derajat II, yaitu ulkus dalam, sampai tendon/tulang

d. Derajat III, ulkus dengan atau tanpa osteomilitis

e. Derajat IV, gangren pada 1-2 jari kaki atau bagian distal kaki, dengan tanpa selulitis (infeksi jaringan)

f. Derajat V, gangren pada seluruh kaki atau sebagian tungkai bawah

Penyembuhan luka ulkus diabetikum: Tipe penyembuhan luka di bagi menjadi 3, yaitu tipe yaitu primary intention healing, secondary intention healing, dan tertiary intention.

\begin{tabular}{lllllllllll}
\hline \hline Jurnal & SMART & Keperawatan & Sekolah & Tinggi & Ilmu & Kesehatan & (STIKes) & Karya & Husada & Semarang
\end{tabular} 
c. Garam

Definisi garam secara fisik adalah benda padatan berwarna putih berbentuk kristal yang merupakan kumpulan senyawa dengan bagian terbesar Natrium Chlorida (>80\%) serta senyawa lainnya seperti Magnesium Chlorida, Magnesium Sulfat,Calsium Chlorida,dan lain -lain. Garam mempunyai sifat / karakteristik higroskopis yang berarti mudah menyerap air, bulk density (tingkat kepadatan) sebesar 0,8 - 0,9 dan titik lebur pada tingkat suhu $80^{\circ} \mathrm{C}$ ( Burhanuddin2001). Digunakan terutama sebagai bumbu penting untuk makanan, sebagai bumbu penting untuk makanan, bahan baku pembuatan logam $\mathrm{Na}$ dan $\mathrm{NaOH}$ ( bahan untuk pembuatan keramik, kaca, dan pupuk ), sebagai zat pengawet ( Mulyono, 2009)

Manfaat garam bagi penyembuhan luka

Garam yang dicampur dengan air hangat akan terbentuk partikel-partikel dengan muatan listrik yang berbeda yaitu ion natrium yang bermuatan positif dan ion klor yang bermuatan negatif. Ketika larutan garam ini diberikan pada bagian yang luka, ion-ion ini akan mengatur tekanan sel-sel di sekitar luka. Tekanan diatur sedemikian rupa sehingga cairan tidak akan keluar dari dalam sel. Hal ini mengakibatkan luka akan menjadi cepat kering.Di samping mengeringkan luka, air garam juga dapat membunuh bakteri yang menyerang luka (terutama bakteri staphylococcus dan streptococcus)

\section{Metode Penelitian}

Jenis penelitian yang akan dilakukan adalah quasi eksperimen dengan rancangan pre test-post test design with control group yaitu dengan melakukan observasi luka ulkus diabetikum sebelum dan sesudah perlakuan (pemberian rendam air garam selama 10 menit, sebelum perawatan luka) dan dibandingan dengan kelompok kontrol yang tidak diberikan perlakuan. 


\section{Hasil Penelitian}

a. Distribusi frekuensi responden berdasarkan jenis kelamin.

Tabel 4.1 Tabel Distribusi Frekuensi Jenis Kelamin Responden.

\begin{tabular}{lcc}
\hline Jenis kelamin & Frekuensi & Persentase(\%) \\
\hline Laki-laki & 18 & 45 \\
Perempuan & 22 & 55 \\
\hline Total & $\mathbf{4 0}$ & $\mathbf{1 0 0}$ \\
\hline
\end{tabular}

b. Distribusi frekuensi responden berdasarkan usia

Tabel 4.2 Tabel Distribusi Frekuensi Usia Responden

\begin{tabular}{lcc}
\hline Usia & Frekuensi & Persentase $(\%)$ \\
\hline 31 tahun -40 tahun & 2 & 5 \\
41 tahun -50 tahun & 11 & 27.5 \\
51 tahun -60 tahun & 14 & 35 \\
61 tahun - 70 tahun & 13 & 32.5 \\
\hline Total & $\mathbf{4 0}$ & $\mathbf{1 0 0}$ \\
\hline
\end{tabular}

c. Distribusi frekuensi responden berdasarkan pendidikan

Tabel 4.3 Distribusi Frekuensi Pendidikan Responden

\begin{tabular}{lcc}
\hline Pendidikan & Frekuensi & Persentase(\%) \\
\hline SD & 13 & 32.5 \\
SMP & 10 & 25 \\
SMA & 10 & 25 \\
Sarjana/Diploma & 7 & 17.5 \\
\hline Total & $\mathbf{4 0}$ & $\mathbf{1 0 0}$ \\
\hline
\end{tabular}

d. Distribusi frekuensi responden berdasarkan pekerjaan

Tabel 4.4 Tabel Distribusi Frekuensi Pekerjaan Responden

\begin{tabular}{lcc}
\hline Pekerjaan & Frekuensi & Persentase (\%) \\
\hline Tidak Bekerja & 14 & 35 \\
Swasta & 20 & 50 \\
PNS/TNI/Polri & 6 & 15 \\
\hline Total & $\mathbf{4 0}$ & $\mathbf{1 0 0}$ \\
\hline
\end{tabular}

e. Distribusi rata-rata proses penyembuhan luka ulkus Diabetikum

Tabel 4.5 Distribusi Proses Penyembuhan Luka Ulkus Diabetikum.

\begin{tabular}{lccc}
\hline \multicolumn{1}{c}{ Proses Penyembuhan Luka } & Mean & SD & N \\
\hline Kel Intervensi & 3.70 & 0.470 & 20 \\
\hline Kel Kontrol & 3.35 & 0.489 & 20 \\
\hline
\end{tabular}

Tabel 4.5 menunjukkan bahwa rata-rata nilai proses penyembuhan luka pada kelompok intervensi (direndam air garam) adalah 3.70, sedangkan rata-rata nilai proses penyembuhan luka pada kelompok kontrol (tidak direndam air garam) adalah 3.35 .

f. Pengaruh perawatan luka rendam air garam terhadap proses penyembuhan luka ulkus diabetikum. Tabel 4.6 Pengaruh perawatan luka rendam air garam terhadap proses penyembuhan luka ulkus diabetikum. 


\begin{tabular}{lccc}
\hline \multicolumn{1}{c}{ Proses Penyembuhan Luka } & N & Mean Rank & p-value \\
\hline Kel Intervensi & 20 & 24 & \\
\cline { 1 - 3 } Kel Kontrol & 20 & 17 & 0.029 \\
\hline
\end{tabular}

Tabel 4.6 didapatkan bahwa mean rank proses penyembuhan luka ulkus diabetikum yang direndam air garam (kelompok intervensi) adalah 24, sedangkan untuk yang tidak direndam air garam adalah 17. Hasil uji statistik didapatkan ada pengaruh perawatan luka rendam air garam terhadap proses penyembuhan luka ulkus diabetikum $(\mathrm{p}$ value $=0.029)$

\section{Pembahasan}

a. Distribusi frekuensi responden berdasarkan jenis kelamin.

Mayoritas responden penderita ulkus DM pada penelitian ini adalah perempuan bisa dipengaruhi oleh faktor risiko penyebab DM lainnya seperti umur dan obesitas. Rakhmadany (2010) menjelaskan Diabetes sering muncul setelah seseorang memasuki usia rawan lebih dari 45 tahun pada mereka yang berat badannya berlebih. Penelitian yang dilakukan oleh Mursyida (2012), menunjukkan ada hubungan yang bermakna antara obesitas dengan kejadian diabetes ( $\mathrm{p}$ value : 0,009).

b. Distribusi frekuensi responden berdasarkan usia

Diabetes sering muncul setelah seseorang memasuki usia rawan, terutama setelah usia 45 tahun pada mereka yang berat badannya berlebih, sehingga tubuhnya tidak peka lagi terhadap insulin. Teori yang ada mengatakan bahwa seseorang $\geq 45$ tahun memiliki peningkatan risiko terhadap terjadinya DM dan intoleransi glukosa yang disebabkan oleh faktor degenerative yaitu menurunnya fungsi tubuh, khususnya kemampuan dari sel beta dalam memproduksi insulin untuk memetabolisme glukosa (Pangemanan, 2014).

c. Distribusi frekuensi responden berdasarkan pendidikan

Pendidikan bisa dikaitkan dengan pengetahuan yang kurang terutama dengan kepatuhan diit dan perawatan kaki sehingga mengarah terjadinya DM dan ulkus DM.

d. Distribusi frekuensi responden berdasarkan pekerjaan 
Hasil penelitian mayoritas pekerjaan responden adalah swasta sebanyak 20 orang (50\%). Hasil penelitian ini berbeda dengan penelitian Isabella V (2014), yang menunjukkan bahwa sebagian besar responden DM adalah tidak bekerja (37,5\%). Hasil penelitian ini juga tidak sesuai dengan teori yang menyebutkan bahwa faktor risiko penderita DM adalah mereka yang memiliki aktivitas minim sehingga pengeluaran tenaga dan energi hanya sedikit (Rakhmadany, 2010).

\section{Distribusi rata-rata proses penyembuhan luka ulkus Diabetikum}

Hasil penelitian menunjukkan bahwa rata-rata nilai proses penyembuhan luka pada kelompok intervensi (direndam air garam) adalah 3.70, sedangkan rata-rata nilai proses penyembuhan luka pada kelompok kontrol (tidak direndam air garam) adalah 3.35. Hasil ini menunjukkan bahwa proses penyembuhan luka yang direndam dengan air garam memiliki nilai lebih tinggi dibandingkan dengan luka yang tidak direndam dengan air garam dengan selisi 0,35. Hal ini disebabkan karena luka yang dirawat menggunakan air garam mengakibatkan luka akan menjadi cepat kering.

\section{Pengaruh perawatan luka rendam air garam terhadap proses penyembuhan luka ulkus diabetikum.}

Hasil penelitian didapatkan ada pengaruh perawatan luka rendam air garam terhadap proses penyembuhan luka ulkus diabetikum $(\mathrm{p}$ value $=0.029$ ). Hasil ini didukung dengan teori bahwa garam yang dicampur dengan air hangat akan terbentuk partikelpartikel dengan muatan listrik yang berbeda yaitu ion natrium yang bermuatan positif dan ion klor yang bermuatan negatif. Ketika larutan garam ini diberikan pada bagian yang luka, ion-ion ini akan mengatur tekanan sel-sel di sekitar luka. Tekanan diatur sedemikian rupa sehingga cairan tidak akan keluar dari dalam sel. Hal ini mengakibatkan luka akan menjadi cepat kering. Di samping mengeringkan luka, air garam juga dapat membunuh bakteri yang menyerang luka (terutama bakteri staphylococcus dan streptococcus).

Hasil penelitian ini juga didukung penelitian yang dilakukan oleh Chinthia Kartikaningtyas (2006), tentang perbedaan kecepatan penyembuhan luka antara perawatan luka pasien pasca operasi herniotomi menggunakan normal salin $(\mathrm{NaCl})$ 
dengan povidine Iodine $10 \%$, hasil penelitian menunjukan penyebuhan luka yang dirawat dengan Normal Saline $(\mathrm{NaCl})$ lebih cepat bila dibandingkan dengan perawatan menggunakan povidone iodine $10 \%$.

\section{Kesimpulan}

Karakteristik responden penelitian : jenis kelamin responden sebagian besar perempuan sebanyak 22 orang (55\%), Umur responden sebagian besar berumur 51-60 tahun sebanyak 14 orang (35\%), Pendidikan responden sebagian besar memiliki pendidikan SD sebanyak 13 orang (32.5\%), Pekerjaan responden sebagian besar swasta sebanyak 20 orang $(50 \%)$. Rata-rata nilai proses penyembuhan luka pada kelompok intervensi (direndam air garam) adalah 3.70, sedangkan rata-rata nilai proses penyembuhan luka pada kelompok kontrol (tidak direndam air garam) adalah 3.35. Ada pengaruh rendam air garam terhadap proses penyembuhan luka ulkus diabetikum $(\mathrm{p}$ value $=0.029)$

\section{Daftar Pustaka}

1. Asmadi, 2008. Konsep Dasar Keperawatan, Jakarta: EGC 
2. Bruner \& Suddartth, 2001. Buku Ajar Keperawatan Medikal Bedah. Edisi 8, Volume 1. Jakarta: Penerbit Buku Kedokteran EGC Perbedaan penyembuhan luka post sikumsisi dengan metode eletro couter dan metode konvensional pada pasien sirkumsisi di Poliklinik Morodadi Boyolali Hamilton, Persis Mary.(1995).DasarDasar Keperawatan Maternitas. EGC. Jakarta

3. Doenges, E Marlyn, 2000. Rencana Asuhan Keperawatan Pedoman untuk Perencanaan Dan Pendokumentasian Perawatan Pasien.

4. Hastono, Santoso.Priyo .(2007). Analisis Data. Jakarta, Penerbit Pustaka Fakultas Kesehatan. Masyarakat-UI

5. Dwi Ariani Sulistyowati (2014). Efektifitas Elevasi Ektermitas bawah terhadap proses penyembuhan ulkus Diabetic." Kosala" JIK Vol 3 No. 1 Maret 2015. Surakarta.

6. Istikomah, Nurul. (2010). Perbedaan Perawatan Luka Dengan Menggunakan Povodine Iodine 10\% Dan NaCl 0,9\% Terhadap Proses Penyembuhan Luka Pada Pasien Post Operasi Prostatektomi Di Ruang Anggrek RSUD Tugurejo Semarang

7. JM Stevens, F Bordui, Vab der Weyde. (1999). Ilmu Keperawatan Jilid 2 Edisi 2. EGC. Jakarta.

8. Mansjoer, Arif. (2000). Kapita Selekta Kedokteran Edisi 3, Medica. Aesculpalus, FKUI, Jakarta.

9. Notoatmojo, S. 2003. Metodologi Penelitian Kesehatan. Cetakan ke dua Edisi Revisi. Jakarta: Rineke Cipta

10. Nursalam, 2003. Konsep Penerapan Metodologi Penelitian Ilmu Keperawatan.Edisi Pertama. Jakarta: Salemba Medika

11. Uli rimadhani masruroh. (2010). Pengaruh penggunaan larutan Nacl 0,9\% dengan larutan betadine $10 \%$ terhadap proses penyembuhan luka post operasi di rumah sakit umum daerah ambarawa semarang

12. WHO.(2014). Male circumcision for HIV prevention dalam http://www.who.int/hiv/topics/maleci rcumcision/en/

13. WHO, (2014). WHO Prequalification of Male Circumcision Devices Dalam http://www.who.int/diagnostics_labo ratory/evaluations/prequalification male_circumcision_devices/en/

14. ------.(2014). New data on male circumcision and HIV prevention: Policy and programme implications dalam http://www.who.int/hiv/pub/malecirc umcision/research_implications/en/ 
15. ------. (2014). Demand for male circumcision rises in a bid to prevent HIV dalam http://www.who.int/bulletin/volumes /84/7/news10706/en/

16. -----. (2014). Male circumcision for HIV control Dalam http://www.who.int/reproductiveheal th/topics/rtis/male_circumcision/en/

17. Wong, Donna L et al. (2009). Buku Ajar Keperawatan Pediatrik volume 1. EGC. Jakarta

18. Yuliaji Siswanto, Heni Purwaningsih, (2011) Perbedaan penyembuhan luka jahitan antara pemberian kompres povidone iodine $10 \%$ dengan kompres nacl $0,9 \%$ pada pasien post operasi hernioraphy di ruang bedah RSUD KRT Setjonegoro Wonosobo Penulis penanggung jawab Hardono, S.Kep., Ns., M.Kep, Didi Suswanto, M.Kes 